\title{
Pengaruh pengawetan pohon berdiri terhadap sifat kimia dan mekanis Bintangur (Callophyllum soulattri) dan Balam (Macaranga conifera (Rch.f. \&
} Zoll) Mull.Arg.)

Effect of the living tree preservation on chemical and mechanical properties of Bintangur (Callophyllum soulattri) and Balam (Macaranga conifera (Rch.f. \& Zoll)

Mull.Arg.)

\author{
Dwi Ajias Pramasari ${ }^{a, \star}$, Sonia Somadona ${ }^{b}$, Evi Sribudiani ${ }^{b}$,Yusup Amin ${ }^{a}$, Didi \\ Tarmadi $^{\mathrm{a},}$, Sulaeman Yusuf ${ }^{\mathrm{a}}$, Ratih Damayanti ${ }^{\mathrm{c}}$,Djarwanto ${ }^{\mathrm{c}}$, Wa Ode \\ Muliastuty Arsyad $^{c}$, Esti Rini Satitic ${ }^{c}$, Syafrinal ${ }^{b}$, M.Mardhiansyah $^{b}$ \\ ${ }^{a}$ Pusat Riset Biomaterial, Badan Riset dan Inovasi Nasional \\ Kawasan Cibinong Science Center, Jl. Raya Bogor Km. 46, Cibinong, Bogor, Indonesia \\ b Jurusan Kehutanan, Fakultas Pertanian, Universitas Riau \\ Jl. Simpang Baru, Kec. Tampan, Kota Pekanbaru, Riau, Indonesia \\ ${ }^{\mathrm{C}}$ Pusat Penelitian dan Pengembangan Hasil Hutan \\ Jl. Gunung Batu No.5, Bogor, Indonesia \\ *E-mail: dwia010@lipi.go.id; dwi.ajias@gmail.com
}

Diterima 01 April 2021 Direvisi 16 Agustus 2021 Disetujui 18 Agustus 2021

\begin{abstract}
ABSTRAK
Teknologi pengawetan kayu dengan metode infus dan bandage-wrapping pada pohon berdiri yang masih hidup merupakan metode baru dalam pengawetan kayu. Metode ini memiliki keunggulan dapat mengawetkan kayu berukuran besar secara mudah. Kayu utuh berukuran besar dibutuhkan untuk bahan baku pembuatan Jalur, yaitu, perahu tradisional khas daerah Riau. Penelitian ini bertujuan untuk mengetahui pengaruh perlakuan pengawetan kayu pada pohon berdiri terhadap karakteristik kayu, terutama sifat kimia dan sifat mekanisnya. Masing-masing sebanyak dua pohon dari jenis kayu alternatif bahan baku pembuatan Jalur yaitu Bintangur (Callophyllum soulattri Burm.f.) dan Balam (Macaranga conifera (Rch.f. \& Zoll) Mull.Arg) diawetkan menggunakan senyawa boron dengan metode infus dan bandage-wrapping. Sebagai kontrol, satu pohon dari masing-masing jenis juga ditebang dan diuji. Sampel kayu yang digunakan dibagi menurut posisi aksial pohon (pangkal, tengah, dan ujung) untuk diamati sifat kimia dan sifat mekanis dengan masing-masing tiga ulangan. Hasil penelitian menunjukkan bahwa posisi aksial mempengaruhi sifat kimia kayu Balam dan Bintangur secara signifikan pada kadar lignin (30-36\%) dan kadar alfa selulosa (48-52\%). Secara umum, sifat mekanis yaitu Modulus of Rupture (MOR) dan Modulus of Elasticity (MOE) meningkat secara signifikan setelah diawetkan, kecuali pada Bintangur untuk metode bandage-wrapping. Hasil analisis sidik ragam dan uji lanjut menunjukkan bahwa perlakuan infus memberikan pengaruh nyata yang positif terhadap sifat kimia dan mekanis kayu Bintangur, sehingga pohon Bintangur yang telah diawetkan menggunakan metode infus dapat direkomendasikan sebagai alternatif bahan baku pembuatan Jalur.
\end{abstract}

Kata Kunci: jalur; metode infus; pengawetan kayu; pohon berdiri; sifat kimia

\section{ABSTRACT}

In this study, novel techniques namely infusion and bandage-wrapping methods were applied to preserve living trees. These methods are easy to apply and can be used to treat a large dimension log which is needed for instance in making Jalur (traditional wooden boat from Riau region). This study aimed to investigate the effect of standing trees preservation treatment on wood characteristics, especially chemical and mechanical properties. Totally, four trees as alternative wood species for Jalur manufacture namely 
Bintangur (Callophyllum soulattri Burm.f.) and Balam (Macaranga conifera (Rch.f. \& Zoll) Mull.Arg. were treated with infusion and bandage-wrapping methods. As control, one tree of each species was also felled and tested. Axial variation within trees on the chemical and mechanical properties at the bottom, middle and top of the tree were investigated. The results showed that the axial position significantly affected the lignin content (30-36\%) and alpha cellulose content (48-52\%) of Balam and Bintangur wood. In general, the mechanical properties, namely the Modulus of Rupture (MOR) and Modulus of Elasticity (MOE) significantly increased after the preservation treatment, except for when Bintangur treated the bandage-wrapping method. One way analysis of variance (ANOVA) and further statistical tests demonstrated that infusion treatment in Bintangur significantly influenced wood chemical and mechanical properties positively. Therefore, Bintangur trees that had been preserved by infusion method could be recommended as material for Jalur making.

\section{Keywords : jalur; infusion method; wood preservation; living tree; chemical properties}

\section{PENDAHULUAN}

Kebutuhan kayu dengan tingkat keawetan dan kekuatan tinggi semakin sulit diperoleh, serta harga yang relatif mahal, sehingga dibutuhkan teknologi pengawetan pada kayu kelas rendah dan menengah untuk memenuhi kebutuhan kayu tersebut (Pangestuti, Lashari, \& Hardomo, 2016). Jalur merupakan salah satu bentuk pemanfaatan kayu berupa perahu dengan panjang berkisar 25-40 m dan lebar bagian tengah berkisar 1,3-1,5 $\mathrm{m}$ yang biasa digunakan untuk kegiatan pacu jalur. Pacu jalur sendiri merupakan suatu kegiatan perlombaan dayung yang dilaksanakan tahunan dan menjadi budaya khas pada daerah Kuantan Singingi, Riau. Selama ini, pemenuhan kayu untuk pembuatan jalur berasal dari kayu kelas kuat tinggi dari famili Dipterocarpacea yang mulai sulit untuk ditemukan, di lain sisi kebudayaan pacu jalur harus tetap dilestarikan (Damayanti et al., 2020; Sribudiani et al., 2019). Oleh karena itu, diperlukan jenis kayu alternatif yang berdiameter besar $(100 \mathrm{~cm})$ dan panjang (minimum $30 \mathrm{~m}$ ) yang ketersediaannya di alam masih banyak ditemukan. Jenis kayu yang berpotensi dijadikan alternatif bahan baku pada pembuatan jalur tersebut karena ketersediaannya yang cukup banyak di daerah Kuantan Singingi, Riau adalah Bintangur (Callophyllum soulattri Burm.f.). dan Balam (Macaranga conifera (Rch.f. \& Zoll) Mull.Arg.). Namun, keduanya tergolong kayu berkualitas rendah dengan kelas awet berkisar II-IV (Damayanti et al., 2020; Sribudiani et al., 2019).

Teknologi pengawetan kayu merupakan upaya untuk meningkatkan umur pakai kayu yang memiliki keawetan alami rendah maupun menengah terutama terhadap serangan rayap sehingga mengurangi biaya akhir dari produk kayu tersebut, serta menghindari pergantian kayu yang terlalu sering (Hunggurami, Ramang, \& Djenmakani, 2014; Pangestuti et al., 2016). Sampel yang biasa digunakan pada teknologi pengawetan kayu konvensional hanya dapat digunakan pada sortimen kayu berukuran kecil, padahal untuk jalur dibutuhkan kayu dengan diameter besar yaitu sekitar $100 \mathrm{~cm}$ agar dapat menampung sekitar 70 pendayung. Hal ini yang mendasari kebutuhan metode pengawetan kayu yang baru di Indonesia yaitu teknologi pengawetan yang dapat dilakukan langsung pada tegakan pohon atau pohon berdiri yang masih hidup dengan memanfaatkan daya kapiler dan osmosis dalam sel pembuluh pohon, sehingga prosesnya lebih efektif dan efisien dibandingkan teknik konvensional.

Metode pengawetan pohon berdiri pada penelitian ini terbagi menjadi dua teknik yaitu metode infus dan metode bandage-wrapping. Prinsip kedua metode ini yaitu dengan memanfaatkan kandungan air pada batang kayu yang merupakan media difusi aktif untuk bahan pengawet yang akan mengikuti transpirasi air melalui daun secara kinetis. Secara singkat, proses memasukkan bahan pengawet 
ke dalam batang pada metode infus menggunakan prinsip mekanis dengan bantuan alat injeksi dan membuat lubang bor riap di sekeliling pohon, sedangkan pada metode bandage-wrapping dengan membiarkan bahan pengawet terdifusi ke dalam pohon dengan cara membalut pohon dengan plastik yang berisikan bahan pengawet melingkari bagian pohon. Bahan pengawet kayu yang digunakan adalah kompleks boron, dikarenakan memiliki kelebihan yaitu murah dan mudah diaplikasikan karena sifatnya yang mudah larut dengan hanya meningkatkan suhu pelarutnya seperti air. Selain itu, boron merupakan bahan pengawet yang telah diijinkan oleh komisi pestisida yang bersifat untuk pencegahan bukan pemberantasan (Hunggurami et al., 2014; Sumaryanto, Hadikusumo, \& Lukmandaru, 2013). Cahyono, Darmawan, Priadi, \& Iswanto (2020) menjelaskan bahwa pengawet boron sudah lama digunakan sebagai bahan pengawet kayu dan cukup efektif meningkatkan keawetan kayu.

Sifat kimia yang berkaitan dengan sifat dasar kayu mempengaruhi sifat-sifat lainnya seperti sifat fisis, keawetan, dan kekuatan kayu. Sementara itu, sifat fisis dan mekanis merupakan sifat yang seringkali tidak bisa dipisahkan terkait dengan kekuatan bahan lignoselulosa sebagai bahan baku produk yang dihasilkan (Nugroho, Bahtiar, Lestari, \& Nawawi, 2013). Menurut Wibisono, Jasni, \& Arsyad (2018), pemanfaatan kayu untuk tujuan tertentu perlu memperhatikan komponen kimia beserta tingkat keawetan kayu. Zat ekstraktif yang terdiri dari bahan organik dan anorganik yang awalnya merupakan cairan yang terdapat dalam rongga sel (protoplasma) pada waktu sel hidup kemudian berubah menjadi cairan yang berada pada dinding sel mati yang berupa getah, lilin, mineral, zat warna, dan gelatin (Fengel \& Wegener, 1995). Selain itu, kadar ekstraktif pada kayu dapat mempengaruhi keawetan alami atau sifat perekatannya (Lukmandaru, 2009). Penambahan bahan pengawet kayu berupa kompleks boron memungkinkan mengubah sifat mekanis berupa kuat tekan dan kuat lentur serta sifat kimia berupa kandungan zat ekstraktif dan komponen kimia lainnya yang diduga akan mempengaruhi jalur yang akan dibuat sebagai produk akhir.

Penelitian sebelumnya yang dilakukan oleh Damayanti et al., (2020) dan Sribudiani et al., (2019) telah melaporkan pengaruh metode pengawetan kayu dengan pengawet kompleks boron pada tegakan pohon berdiri kayu Balam dan Bintangur terhadap sifat fisis dan perpindahan bahan pengawet boron yang dilihat dari daya penetrasi dan retensi dari bahan pengawet serta anatomi kayu hasil pengawetan. Namun pengaruh metode infus dan bandage-wrapping pada tegakan pohon berdiri terhadap karakteristik sifat kimia dan sifat mekanis kayu Balam dan Bintangur hasil pengawetan belum dilaporkan sebelumnya. Oleh karena itu, tujuan penelitian ini adalah mengetahui pengaruh metode pengawetan kayu pada pohon berdiri terhadap karakteristik kayu khususnya sifat kimia serta sifat mekanis sebelum dan sesudah pengawetan. Hal ini juga menjadi salah satu upaya untuk lebih memahami karakteristik kayu hasil pengawetan dari metode kayu berdiri sebagai bahan baku jalur.

\section{BAHAN DAN METODE}

\subsection{Bahan}

Bahan yang digunakan dalam penelitian ini berupa kayu Bintangur (Callophyllum soulattri Burm.f.) dan Balam (Macaranga conifera (Rch.f. \& Zoll) Mull.Arg.) yang telah diberi perlakuan pengawetan dengan metode infus selama 5 bulan (April-Agustus 2019) dan metode bandage-wrapping selama 4 bulan (AprilJuli 2019). Selain itu, sebagai kontrol digunakan sampel kayu Balam dan Bintangur tanpa diberi perlakuan pengawetan. Metode pengawetan yang dilakukan pada kedua jenis pohon tersebut telah dijelaskan oleh penelitian sebelumnya yang dilakukan oleh Damayanti et al., (2020) dengan menggunakan komplek boron $\left(\mathrm{Na}_{2} \mathrm{~B}_{4} \mathrm{O}_{7 .} 10 \mathrm{H}_{2} \mathrm{O}\right.$.) sebagai bahan pengawet. 
Tabel 1. Sampel Pohon yang Digunakan pada Penelitian

\begin{tabular}{llll} 
No. & Jenis Pohon & Daerah & Perlakuan \\
\hline 1 & Bintangur & KPHP Minas Tahura & Kontrol \\
\hline 2 & Bintangur & KPHP Minas Tahura & Bandage-wrapping \\
\hline 3 & Bintangur & Rumbio & Infus \\
\hline 4 & Balam & KPHP Minas Tahura & Kontrol \\
\hline 5 & Balam & KPHP Minas Tahura & Bandage-wrapping \\
\hline 6 & Balam & Rumbio & Infus \\
\hline
\end{tabular}
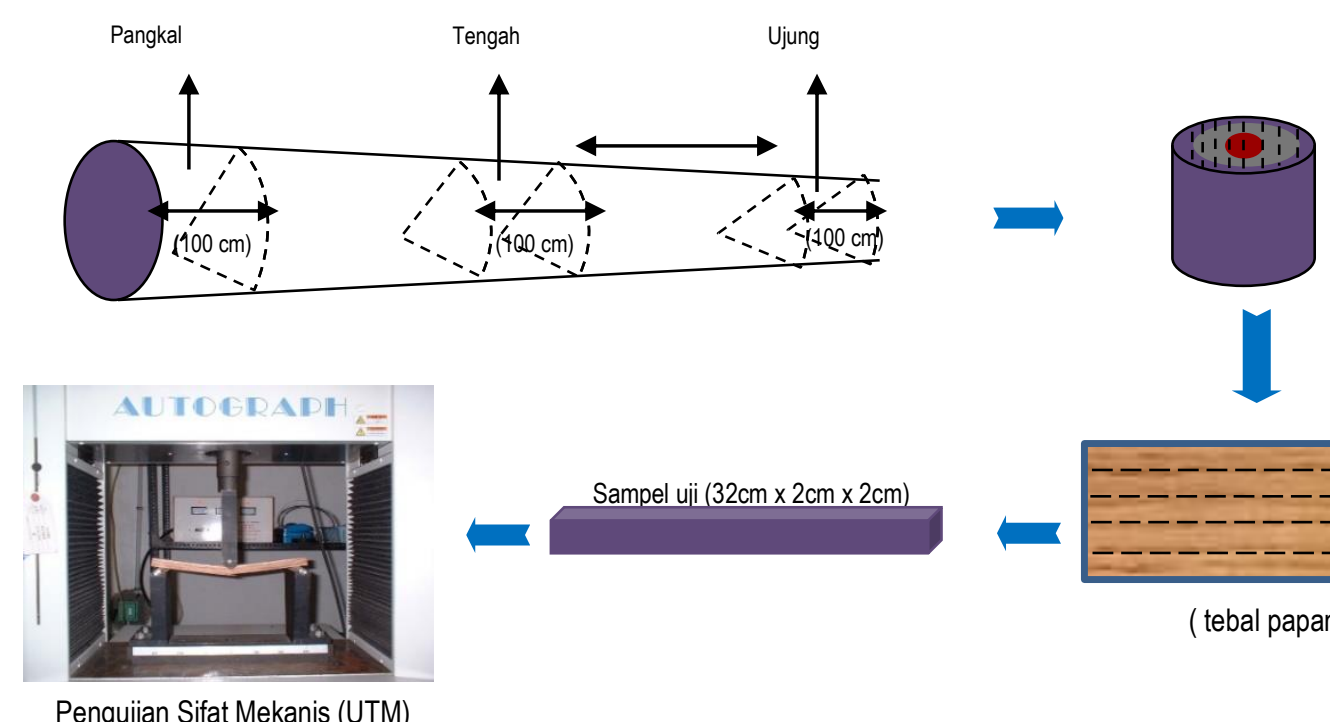

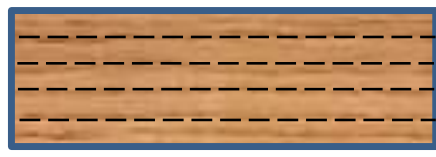

( tebal papan $3 \mathrm{~cm}$ )

Gambar 1. Skema Proses Pembuatan Sampel untuk Pengujian Sifat Mekanis

Pohon Bintangur dan Balam tanpa perlakuan (kontrol) dan metode bandagewrapping berasal dari dari KPHP Minas Tahura, Riau, sedangkan pohon untuk metode infus berasal dari hutan masyarakat (adat) Rumbio. Detail sampel pohon yang digunakan pada penelitian ini disajikan pada Tabel 1. Seluruh sampel pohon yang digunakan pada penelitian ini sebagaimana penelitian sebelumnya dalam Damayanti et al., (2020) dan Sribudiani et al., (2019).

\subsection{Metode Penelitian}

\subsubsection{Persiapan bahan baku}

Pohon sampel yang sudah diberi perlakuan maupun kontrol ditebang dan dipotong hingga bagian bebas cabang, kemudian diambil sampel log kayu berdasarkan posisi aksial pohon yaitu bagian pangkal, tengah, dan ujung. Pada analisis sifat kimia, potongan kayu yang sudah terbagi berdasarkan posisi aksial pohon dilakukan pencacahan, penggilingan, dan pengayakan untuk memperoleh serbuk kayu dengan ukuran 40-60 mesh. Sampel serbuk kayu dikeringudarakan kemudian disimpan dalam kantong plastik untuk digunakan sebagai contoh uji.

Untuk pengujian sifat mekanis (Gambar 1), pengambilan sampel dilakukan dengan cara memotong batang kayu menjadi log sepanjang $100 \mathrm{~cm}$, untuk selanjutnya dibuat papan tangensial dengan ketebalan $3 \mathrm{~cm}$ dan lebar disesuaikan dengan diameter sampel log kayu $( \pm 30 \mathrm{~cm})$. Papan kemudian dikeringkan sampai mencapai kadar air kering udara, dan dipotong dengan ukuran $32 \mathrm{~cm} \times 2 \mathrm{~cm} \times 2 \mathrm{~cm}$ (Amin, Wahyuni, Darmawan, \& Dwianto, 2011). Ukuran 
diameter sampel log kayu yang berbeda berpengaruh terhadap banyaknya jumlah

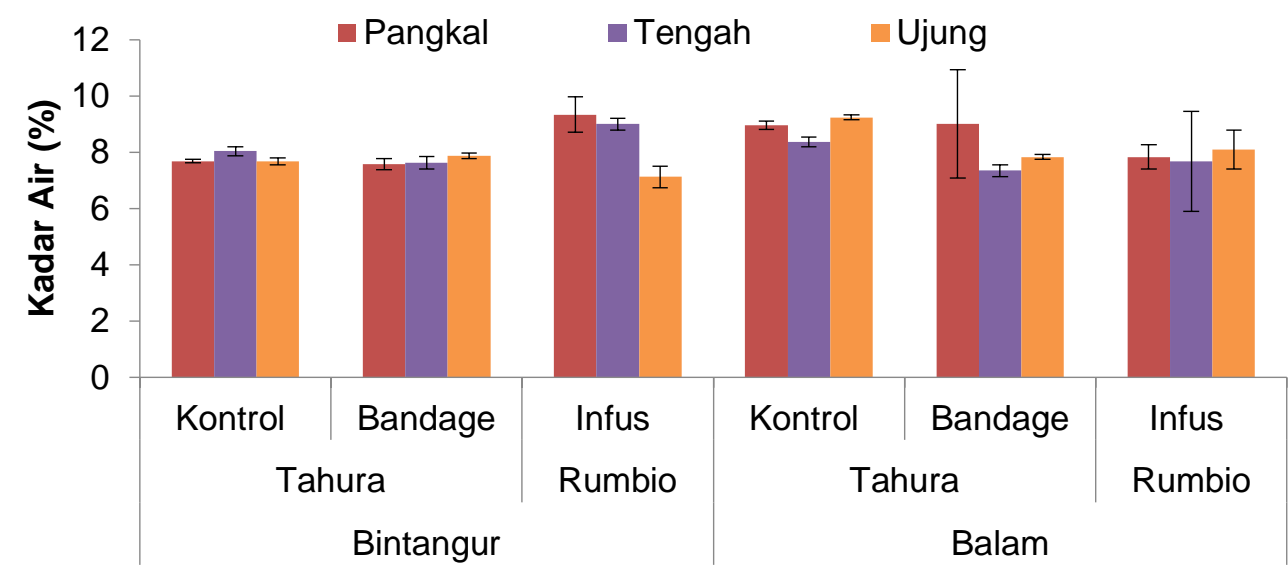

Gambar 2. Rata-rata Kadar Air Kayu Balam dan Bintangur

sampel uji mekanis yang dihasilkan yaitu 15-48 sampel uji per papan. Sampel yang dipilih adalah yang bebas cacat sebanyak tiga sampel per bagian aksial pohon (panjang, tengah, dan ujung) dengan mempertimbangkan keterwakilan dari variasi radial (bagian luar, tengah dan dekat empulur), serta memiliki serat lurus. Pengambilan sampel tidak dibedakan berdasarkan kayu teras dan gubal, karena secara visual jenis kayu yang diuji tidak menampakkan perbedaan yang jelas antara bagian kayu teras dan gubalnya.

\subsubsection{Analisis sifat kimia dan sifat mekanis}

Analisis sifat kimia kayu meliputi analisis kadar air (TAPPI, 1996) , kadar abu (TAPPI, 1996), kadar ekstraktif (TAPPI, 1996), kadar holoselulosa (Wise \& D'Addieco, 1946), kadar a- Selulosa (Rowell, 2012) dan analisis total lignin yang terdiri dari lignin larut asam dan tidak larut asam (Sluiter et al., 2011). Pengujian sifat mekanis dilakukan dengan mengacu pada British Standard (BS 373, 1957) menggunakan alat Universal Testing Machine (UTM) Shimadzu dengan kapasitas beban maksimal $50 \mathrm{kN}$ dan kecepatan pembebanan $5 \mathrm{~mm} /$ menit (Amin et al., 2011). Parameter sifat mekanis yang diuji meliputi Modulus of Elasticity (MOE) atau modulus elastisitas dan Modulus of Rupture (MOR) atau modulus patah.

\subsubsection{Analisis data}

Analisis data dari sifat kimia dan mekanis pada penelitian ini menggunakan rancangan acak lengkap (RAL) faktorial dua faktor dengan faktor pertama adalah metode pengawetan dan faktor kedua adalah posisi batang secara aksial pada setiap pohon yang digunakan sebanyak tiga ulangan. Respon dari pengamatan yang dilakukan adalah sifat kimia dan sifat mekanis. Data yang didapatkan dianalisis varians (ANOVA) satu arah dengan alat bantu uji statistik berupa Statistical Tool for Agricultural Research (STAR). Apabila terdapat perbedaan yang nyata, dilakukan uji lanjut (post-hoc) berupa Duncan's Multiple Range Test (DMRT) pada taraf uji $5 \%$.

\section{HASIL DAN PEMBAHASAN}

\subsection{Karakteristik Sifat Kimia Kayu hasil Metode Infus dan Bandage- Wrapping}

\subsubsection{Kadar air dan kadar abu}

Hasil penelitian mengenai rata-rata kadar air kayu Balam dan Bintangur ditunjukkan pada Gambar 2. Kadar air perlakuan infus pada Bintangur memiliki kecenderungan lebih tinggi dibandingkan jenis perlakuan lainnya (kontrol dan bandage-wrapping), serta pada bagian ujungnya memiliki nilai terendah. Hal ini sejalan dengan analisis sidik ragam pada taraf $5 \%$ yang menunjukkan bahwa jenis perlakuan dan bagian aksial memiliki perbedaan yang nyata dan faktor interaksi 
keduanya memiliki pola yang sama. Hasil uji lanjut menunjukkan bahwa bagian ujung pada perlakuan infus memiliki perbedaan nyata dengan bagian aksial pohon lainnya. Sebaliknya, pada pohon Balam (Gambar 2) terlihat kadar air Balam kontrol relatif lebih tinggi dibandingkan dengan perlakuan lainnya. Namun, kadar air pada Balam nilainya tidak berbeda secara signifikan, terbukti dari analisis sidik ragam pada taraf $5 \%$. Hal ini menunjukkan bahwa kadar air pada Balam tidak dipengaruhi oleh jenis perlakuan pengawetan dan bagian aksial pohon.

Kadar air kayu tidak terlepas dari sifat kayu itu sendiri yaitu mampu menyerap dan melepaskan air (sifat higroskopis), selain itu, berhubungan juga dengan jenis kayu serta lingkungan dimana kayu tersebut diletakkan. Di lain sisi, kadar air kayu yang tinggi akan membuat kayu menjadi lembab dan mempermudah serangan jamur serta organisme perusak kayu yang mengakibatkan keawetan kayu mengalami penurunan (Bahanawan, Darmawan, \& Dwianto, 2020; Sokanandi, Pari, \& Setiawan, 2014). Hasil yang didapatkan pada penelitian ini menunjukkan bahwa kadar air kayu sampel yang diperoleh lebih rendah dibandingkan kadar air dari penelitian sebelumnya oleh Sribudiani et al., (2019) untuk sampel kayu yang sama. Hal ini dimungkinkan akibat proses pengeringan pada serbuk kayu ketika persiapan bahan baku untuk analisis kimia. Penurunan kadar air dari suatu bahan dapat disebabkan oleh proses pengeringan (Bahanawan et al., 2019; Pramasari et al., 2020).

Gambar 3 menunjukkan bahwa kadar abu bagian pangkal pada metode infus baik Balam maupun Bintangur memiliki nilai paling tinggi dibandingkan dengan bagian lainnya. Hal ini diduga karena bagian pangkal merupakan bagian paling bawah dari pohon yang menyerap unsur mikro paling banyak dibandingkan dengan bagian lainnya. Analisis sidik ragam menunjukkan kadar abu pada Bintangur dipengaruhi bagian aksial pohon dan interaksi antara jenis perlakuan dan bagian aksial pohon. Uji lanjut menunjukkan bahwa bagian pangkal perlakuan infus memiliki nilai tertinggi dan berbeda nyata dibandingkan lainnya. Hal ini berbeda dengan analisis sidik ragam kadar abu pada Balam yang menunjukkan tidak berbeda nyata antara kontrol dengan pohon yang dilakukan pengawetan, walaupun nilai kadar abu bagian kontrol cenderung lebih rendah dibandingkan dengan perlakuan lainnya (Gambar 3). Kadar abu berkaitan dengan daya serap pohon terhadap unsur mikro yang berasal dari tanah, hal ini yang membuat unsur mikro tersebut harus dikembalikan ke tanah dengan proses pemupukan maupun pemberian abu (Pasaribu, Sipayung, \& Pari, 2007). Jika diklasifikasikan komponen kimia kayu daun lebar kadar abu Balam dan Bintangur termasuk kelas sedang (Departemen Pertanian, 1976).

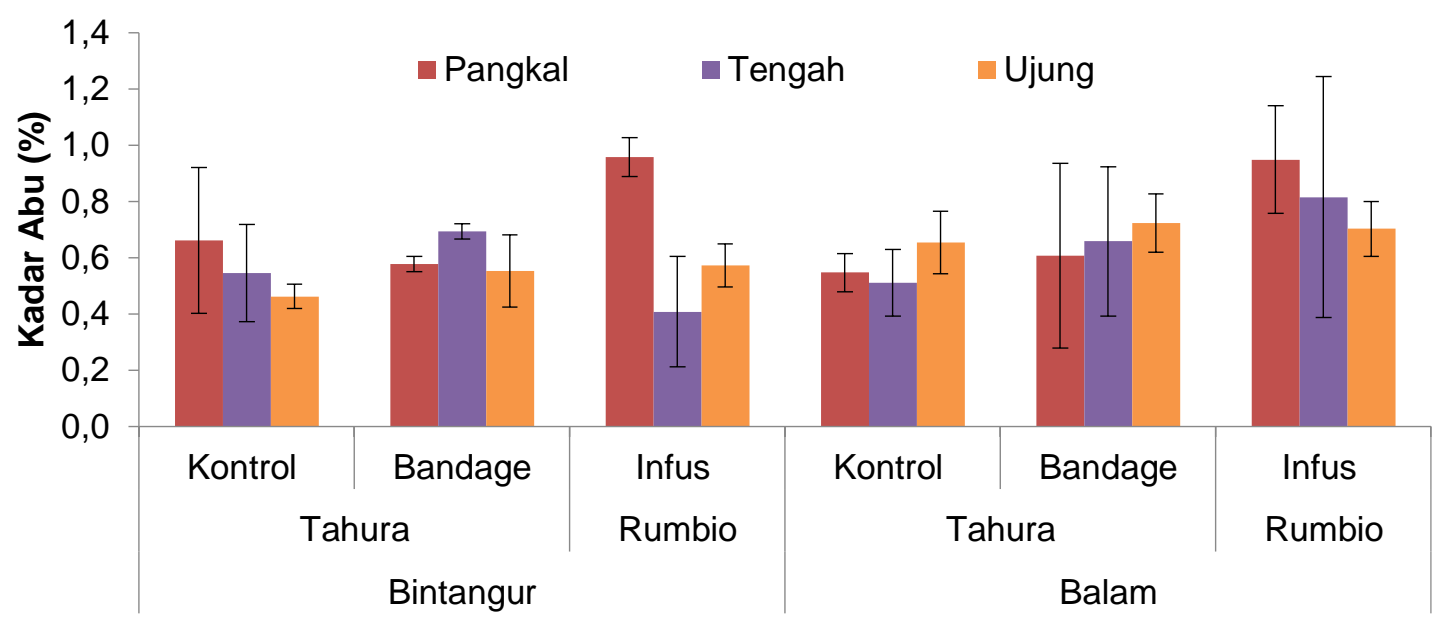

Gambar 3. Rata-rata Kadar Abu Kayu Balam dan Bintangur 


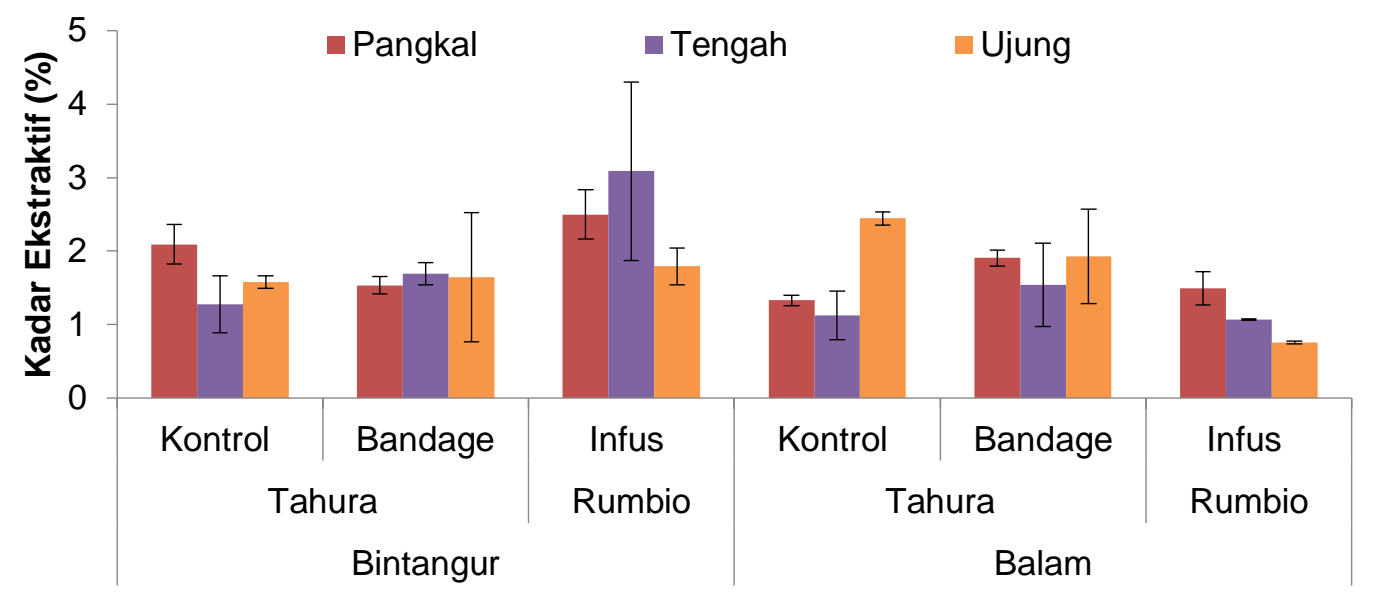

Gambar 4. Rata-rata Kadar Ekstraktif Kayu Balam dan Bintangur

\subsubsection{Kadar ekstraktif dan kadar lignin}

Berdasarkan Gambar 4, kadar ekstraktif pada kayu Bintagur relatif memiliki nilai yang sama pada bagian ujung baik kontrol, bandage maupun infus. Sebaliknya pada Balam, nilai ekstraktif pada bagian ujung relatif menurun. Apabila komponen ekstraktif ini dihubungkan dengan klasifikasi jenis daun lebar Indonesia, kedua jenis kayu Bintangur dan Balam termasuk klasifikasi rendah, kecuali pada perlakuan infus, bintangur termasuk sedang (Departemen Pertanian, 1976). Zat ekstraktif pada kayu dapat bersifat racun untuk serangga maupun mikroorganisme, sehingga mempengaruhi keawetan alami dari pohon tersebut. Kadar ekstraktif yang tinggi dapat meningkatkan keawetan kayu terhadap organisme perusak kayu (Achmadi, 1990; Martawijaya, 1996).

Pada pohon Bintangur menunjukkan bahwa perlakuan infus memiliki nilai ratarata kadar ekstraktif paling tinggi dibandingkan lainnya (Gambar 4), hal ini sejalan dengan analisis sidik ragam yang menyatakan bahwa perlakuan pengawetan pada pohon berpengaruh terhadap kandungan ekstraktifnya. Hal ini dimungkinan karena penambahan bahan pengawet kayu (boron) yang digunakan sehingga meningkatkan kadar ekstraktif dari pohon yang mengalami perlakuan pengawetan. Boron memiliki sifat non polar, pengujian kadar ekstraktif yang menggunakan etanol-benzena pada penelitian ini berfungsi untuk mengekstrak senyawa semi polar dan polar, sehingga penambahan boron yang bersifat non polar menyebabkan peningkatan kadar ekstraktif. Namun, bagian aksial pohon tidak berpengaruh secara nyata pada kadar ekstraktif Bintangur. Berbeda dengan Balam, hasil sidik ragam menunjukkan kondisi perlakuan dan bagian aksial berpengaruh nyata terhadap kadar ekstraktifnya. Uji lanjut menunjukkan bahwa perlakuan infus memiliki perbedaan nyata dibandingkan dengan perlakuan lainnya serta bagian aksial pada pohon Balam infus saling berbeda nyata. Pada bagian pangkal Balam, perlakuan infus memiliki nilai tertinggi dan semakin menurun nilainya pada bagian lainnya. Jika dihubungkan dengan penelitian Damayanti et al., (2020), terlihat bahwa daya penetrasi pengawet boron pada perlakuan infus terutama pada Balam yang memiliki nilai terendah di bagian ujung, hal ini yang memungkinkan nilai kadar ekstraktif bagian ujung Balam memiliki nilai terendah. Hasil penelitian ini berbeda dengan Yunanta, Lukmandaru, \& Fernandes (2014) yang menunjukkan bahwa peningkatan kadar ekstraktif dari pangkal ke ujung akibat adanya komponen ekstraktif polar seperti gula serta terbentuknya komponen non polar yang lebih banyak pada bagian ujung.

Perbedaan sifat kayu pada jenis yang sama dapat disebabkan oleh beberapa 


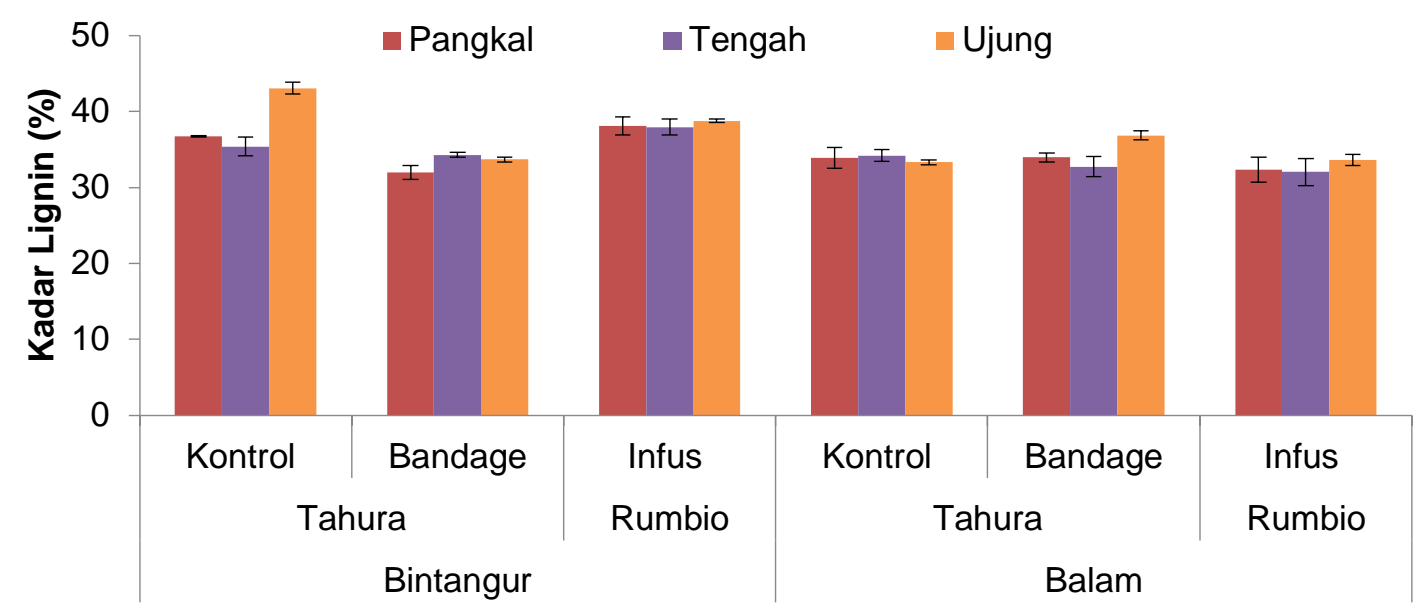

Gambar 5. Rata-rata Kadar Lignin Kayu Balam dan Bintangur

kemungkinan seperti lokasi tempat tumbuh yang dapat memberikan variasi terhadap dimensi sel yang terbentuk karena adanya pengaruh tempat tumbuh seperti perbedaan kondisi tanah, cuaca, maupun iklim setempat (Achmadi, 1990). Zat ekstraktif mengisi rongga sel dan dinding sel serat maupun sel pori. Jumlah ekstraktif larut alkohol benzena yang relatif lebih banyak menjamin kayu tersebut lebih tahan terhadap serangan rayap. Berdasarkan hal tersebut, terdapat kemungkinan bahwa perlakuan infus pada Bintangur terutama bagian tengah memiliki ketahanan lebih terhadap rayap karena memiliki nilai ekstraktif yang lebih besar dibandingkan bagian lainnya. Namun hal ini juga harus diteliti lebih lanjut terkait jenis kandungan ekstraktifnya yang memiliki zat beracun bagi rayap, cendawan dan hama lainnya karena keawetan kayu tidak terlepas dari jenis organisme yang menyerang kayu tersebut (Jasni, Pari, \& Satiti, 2016).

Dari Gambar 5 terlihat bahwa kandungan lignin pada Bintangur bandagewrapping memiliki rata-rata nilai terendah dibandingkan perlakuan infus dan kontrol, jika dilihat dari posisi aksial pohon terlihat bagian ujung cenderung memiliki nilai tertinggi dibandingkan bagian lainnya walaupun perbedaannya tidak terlalu signifikan. Hal ini diperkuat dari analisis sidik ragam yang menyatakan bahwa kadar lignin Bintangur dipengaruhi oleh perlakuan yang diberikan dan interaksi antara perlakuan dengan bagian aksial pohon, namun tidak dipengaruhi oleh bagian aksial pohon. Kadar lignin pada pohon Bintangur infus bagian ujung memiliki nilai tertinggi sejalan dengan uji lanjut yang menyatakan bahwa perlakuan infus Bintangur berbeda nyata dibandingkan pohon lainnya. Peningkatan kadar lignin dari pangkal ke ujung dikarenakan pada bagian ujung pohon terdapat lebih banyak sel-sel baru dibandingkan bagian pangkal (Zaki, Muhammed, Shafie, \& Daud, 2012).

Lignin menentukan sifat fisis dan mekanis kayu, selain sebagai perekat antar satu sel dengan sel lainnya (Nugroho et al., 2013). Kadar lignin yang tinggi memungkinkan juga kayu lebih tahan terhadap kerusakan rayap karena lignin sulit dirombak oleh organisme perusak kayu (Loiwatu, 2016). Jika dihubungkan rata-rata kandungan lignin dengan klasifikasi daun lebar Indonesia, kedua jenis kayu Bintangur dan Balam termasuk tinggi dengan kadar lignin keduanya lebih dari 33\% (Departemen Pertanian, 1976). Kadar lignin pada penelitian ini merupakan total kadar lignin larut asam dan kadar lignin tidak larut asam.

Pada Balam, nilai rata-rata antar perlakuan hampir setara, namun dari analisis sidik ragam menunjukkan bahwa perlakuan pengawetan, bagian aksial pohon, serta interaksi keduanya berpengaruh pada kandungan lignin Balam. Boron sebagai bahan pengawet 


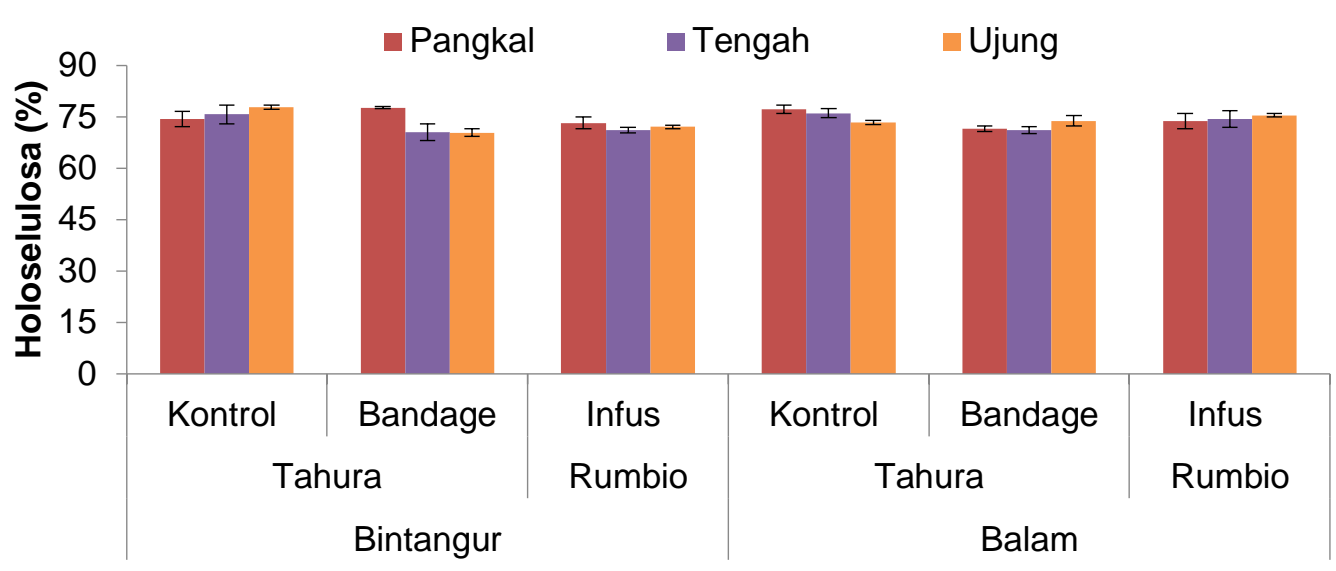

Gambar 6. Rata-rata Kadar Holoselulosa Kayu Balam dan Bintangur

kayu memiliki sifat beracun terhadap serangga, dan boron mudah berinteraksi dengan lignin membentuk kompleks yang cukup stabil (Lelana \& Ismanto, 2011). Hal ini yang diduga yang menyebabkan kandungan lignin meningkat akibat penambahan boron sebagai bahan pengawet kayu. Bagian ujung Balam bandage-wrapping memiliki nilai tertinggi sejalan dengan uji lanjut yang menunjukkan bahwa bagian ujung Balam bandage-wrapping berbeda nyata dibandingkan lainnya. Dengan kandungan lignin tertinggi pada Bintangur yang diinfus memungkinkan kayu Bintangur yang telah diawetkan memiliki kekuatan dan ketahanan lebih baik dibandingkan Balam dan perlakuan lainnya.

\subsubsection{Kadar holoselulosa dan a-selulosa}

Kadar holoselulosa pada Bintangur maupun Balam mengalami penurunan dibandingkan kontrol (Gambar 6). Kadar holoselulosa yang diperoleh berada pada nilai di atas $70 \%$ dikarenakan kandungan holoselulosa yang masih berkaitan dengan jumlah selulosa dan hemiselulosa yang terkandung dalam sampel. Jika diklasifikasikan menurut klasifikasi jenis kayu daun lebar, kedua kayu tersebut memiliki kadar holoselulosa yang tinggi (Departemen Pertanian, 1976). Fengel \& Wegener (1995) menyatakan bahwa kadar holoselulosa berhubungan terbalik dengan kadar lignin, apabila kayu memiliki kadar holoselulosa tinggi maka kadar ligninnya rendah. Dengan kata lain, berat kayu bebas ekstraktif merupakan penambahan kadar holoselulosa dan kadar lignin. Namun pada penelitian ini, kecenderungan pola hubungan antara kadar holoselulosa dan lignin yang sesuai dengan teoritis hanya pada pohon Bintangur perlakuan pengawetan, baik bandage maupun infus.

Perbedaan yang signifikan pada pohon Bintangur antara kontrol dan perlakuan pengawetan terutama infus dapat dimungkinkan karena kondisi lingkungan yang berbeda, salah satunya kondisi mineral tanah yang berakibat perbedaan kandungan kimia dan sintesis komponen kayu (Luostarinen \& Hakkarainen, 2019). Namun, bagian pangkal Bintangur yang mendapat perlakuan bandage memiliki nilai yang hampir sama dengan bagian ujung kontrol Bintangur. Pada Balam, polanya berbeda dengan Bintangur dimana kadar holoselulosa, bagian ujung Balam nilainya cenderung meningkat ke bagian pangkal. Pada umumnya, bagian pangkal kayu memiliki ketebalan dinding sel yang lebih tinggi dibandingkan bagian lainnya sehingga holoselulosa yang merupakan fraksi karbohidrat penyusun dinding sel sekunder tersebut yang terkandung akan lebih tinggi (Sunyata, 2011). Hasil analisis sidik ragam menunjukkan perlakuan pada pohon, posisi aksial, dan interaksi keduanya berpengaruh terhadap kadar holoselulosa dari Bintangur. Dari uji lanjut menunjukkan bahwa perlakuan bandagewrapping terutama bagian pangkal berbeda dengan lainnya pada pohon Bintangur. 


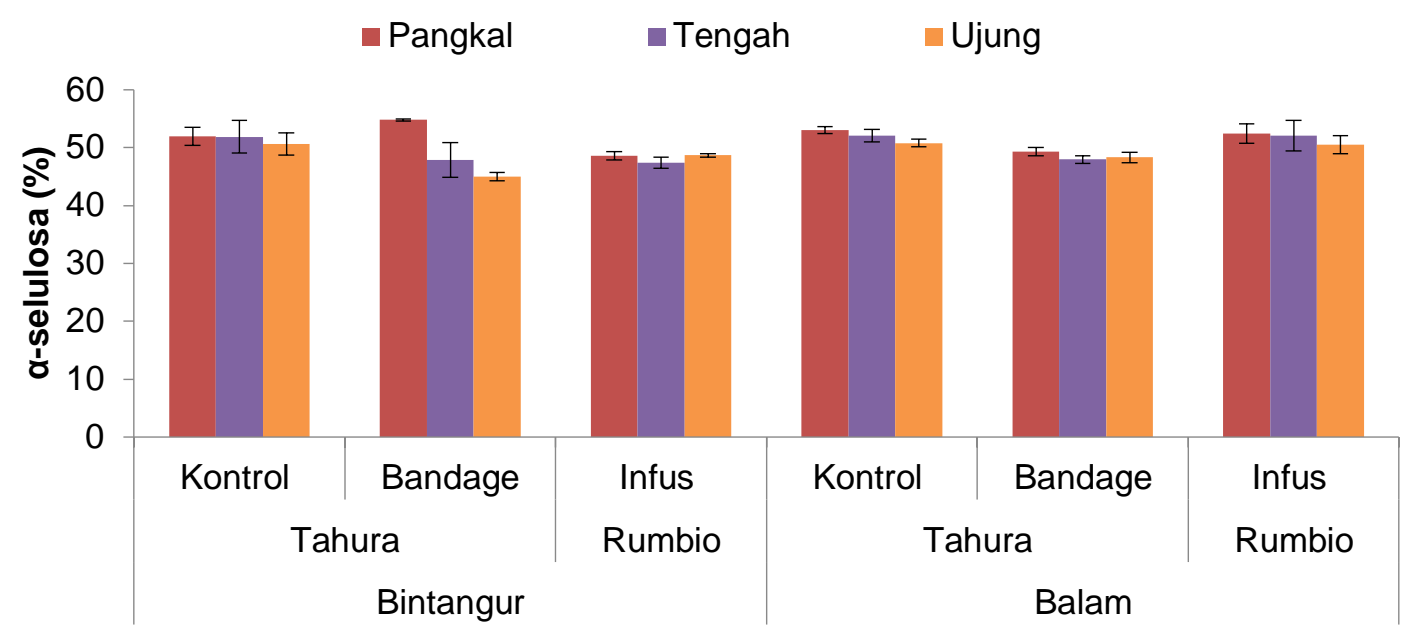

Gambar 7. Rata-rata Kadar a-selulosa Kayu Balam dan Bintangur

Pada pohon Balam, hasil analisis sidik ragam menunjukkan bahwa perlakuan pohon berpengaruh nyata terhadap kadar holoselulosa dari Balam. Perlakuan pengawetan berpengaruh terhadap kadar holoselulosa diduga akibat dari pengaruh pengawetan kayu terhadap lignin oleh boron dimana adanya hubungan terbalik antara kadar holoselulosa dengan kadar lignin (Fengel \& Wegener 1995).

Hasil pengujian kadar alfa selulosa seperti Gambar 7, nilainya relatif tidak mengalami perubahan signifikan dan cenderung mengalami penurunan dari bagian pangkal ke ujung. Sejalan dengan penelitian Yunanta et al., (2014) yang menyatakan kadar alfa selulosa memiliki kecenderungan menurun dari bagian pangkal kayu ke bagian ujungnya, kemungkinan akibat kandungan gula nonselulosa dengan berat molekul rendah lebih banyak terdapat pada bagian ujung kayu yang baru terbentuk. Berdasarkan hasil analisis sidik ragam menyatakan bahwa perlakuan pengawetan kayu, bagian aksial kayu, dan interaksi keduanya mempengaruhi kadar alfa selulosa kayu Bintangur, sedangkan pada kayu Balam hanya perlakuan pengawetan kayu dan bagian aksial kayu yang mempengaruhi kadar alfa selulosa dimana Balam bandage-wrapping berbeda dengan perlakuan lainnya dan bagian aksial berbeda nyata di setiap pohon. Seperti halnya dengan kadar holoselulosa yang dipengaruhi oleh kandungan lignin yang membentuk komplek stabil dengan boron, hubungan kadar holoselulosa dan alfa selulosa sejalan. Hal ini diduga yang menyebabkan pengaruh perlakuan pengawetan terhadap kadar alfa selulosa. Penelitian Lestari et al., (2017) dan Pramasari et al., (2015) menunjukkan bahwa bagian aksial pohon tidak mempengaruhi kandungan alfa selulosa dari kayu Jati Platinum. Kadar alfa selulosa pada bagian pangkal Bintangur bandagewrapping memiliki pola yang sama dengan nilai holoselulosanya, sehingga kemungkinan yang menyebabkan kadar holoselulosa tinggi dikarenakan fraksi alfa selulosa yang cukup besar. Jika dihubungkan dengan klasifikasi jenis daun lebar Indonesia, kadar alfa selulosa kedua jenis kayu Bintangur dan Balam termasuk tinggi dikarenakan kadarnya lebih dari $45 \%$ (Departemen Pertanian, 1976).

Rata-rata nilai kadar alfa selulosa terendah adalah pada Bintangur infus, hal ini mengindikasikan bahwa serangan rayap akan sulit terjadi. Semakin tinggi nilai alfa selulosa semakin mudah mengalami kerusakan yang diakibatkan oleh serangan serangga terutama rayap. Rayap adalah serangga sosial yang merombak selulosa menjadi senyawa yang lebih sederhana untuk dikonsumsi. Rayap lebih memilih campuran selulosa dan lignin dibandingkan hanya selulosa saja, sehingga semakin 


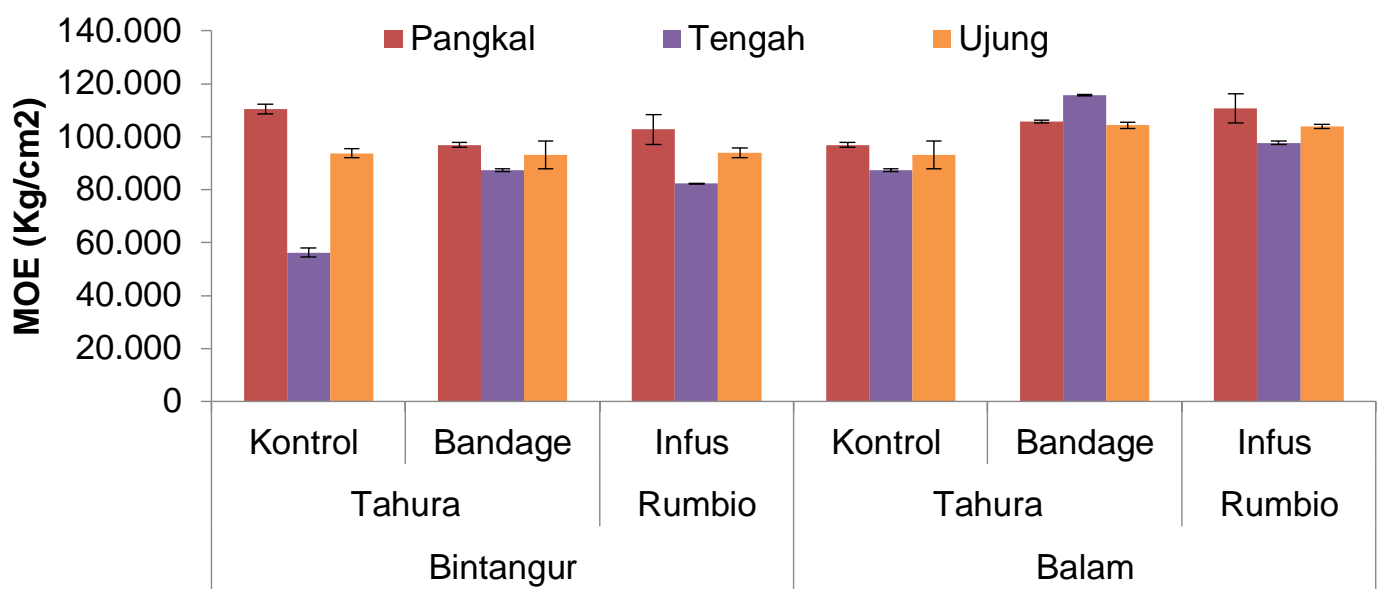

Gambar 8. Rata-rata MOE Kayu Balam dan Bintangur

banyak selulosa dan lignin secara tidak langsung akan menurunkan keawetan kayu (Jasni et al., 2016; Wibisono et al., 2018). Pada penelitian pengawetan pohon berdiri yang dilakukan oleh Fan, Wang, Yu, Deng, \& Chen (2016), kadar selulosa dipengaruhi oleh perlakuan pengawetan, terlihat dari penurunan puncak dan densitas pita akibat adanya reaksi antara bahan pengawet dengan selulosa menggunakan analisa komponen kimia dengan FTIR (Fourier Transform Infrared Spectroscopy). Namun secara garis besar perlakuan pengawetan pada penelitian Fan et al., (2016) tidak berpengaruh terhadap komponen kimia kayu yang mengalami perlakuan.

\subsection{Karakteristik Sifat Mekanis Kayu hasil Metode Infus dan Bandage-} Wrapping

\subsubsection{Modulus of elasticity (MOE) atau modulus elastisitas}

Pada Gambar 8 terlihat bagian pangkal kontrol Bintangur memiliki nilai MOE atau kekakuan paling tinggi dibandingkan lainnya. Namun, jika dilihat dari rata-rata keseluruhan MOE dari semua bagian pohon, nilai MOE tertinggi pada pohon Bintangur infus kemudian bandage dan terkecil kontrol. Jika dilihat dari klasifikasi Den Berger, nilai MOE pohon Bintangur kontrol termasuk pada kelas kuat IV dan meningkat menjadi kelas kuat III untuk pohon Bintangur perlakuan (infus dan bandage) (Yani, 2013).
Nilai MOE pada setiap bagian aksial pohon Bintangur kontrol dan perlakuan memiliki pola yang sama tertinggi di pangkal kemudian menurun pada bagian tengah dan meningkat kembali pada bagian ujung. Jika dihubungkan dengan nilai berat jenis pohon Bintangur dan Balam, baik kontrol maupun perlakuan yang telah diteliti sebelumnya oleh Sribudiani et al., (2019), menunjukkan pola yang sejalan antara nilai berat jenis dengan nilai MOE pada Bintangur dimana bagian pangkal memiliki nilai tertinggi dibandingkan bagian lainnya serta nilai pohon kontrol cenderung lebih besar dari perlakuan. Hal ini mengindikasikan bahwa nilai MOE yang lebih tinggi tersebut karena pengaruh berat jenis yang lebih tinggi dikarenakan dinding sel pada pohon yang tebal (Prakosa, Muttaqin, \& Suhestin, 2020). Hasil analisis sidik ragam menunjukkan bahwa nilai MOE pada Bintangur dipengaruhi oleh perlakuan pengawetan, bagian aksial dan interaksi keduanya. Hanya pada perlakuan Bintangur bandage nilai MOE pangkal dan ujung tidak berbeda nyata secara statistika.

Perlakuan bandage - wrapping memiliki rata-rata nilai MOE tertinggi pada Balam dibandingkan metode infus maupun kontrol. Nilai MOE pada Balam sesuai dengan klasifikasi Den Berger termasuk pada kelas kuat III baik kontrol maupun perlakuan pengawetan (Yani, 2013). Nilai MOE berdasarkan bagian aksial pada 


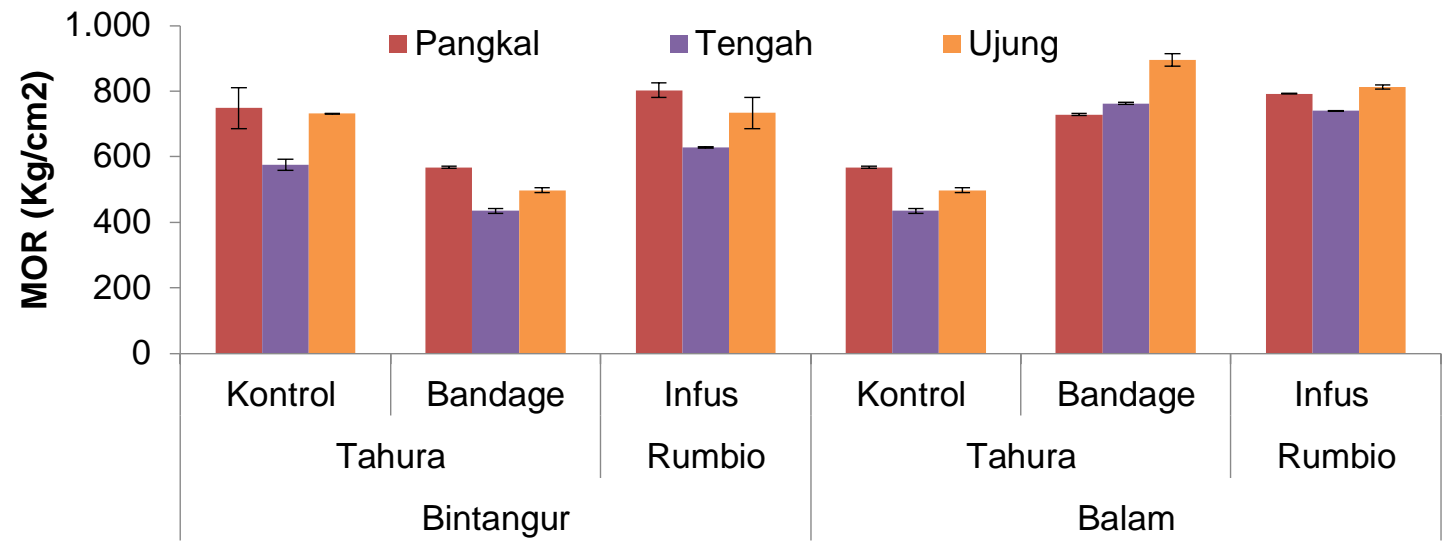

Gambar 9. Rata-rata MOR Kayu Balam dan Bintangur

pohon Balam terlihat pola Balam yang diawetkan dengan metode bandagewrapping berbeda dibandingkan lainnya, yang mana bagian tengah memiliki nilai tertinggi dibandingkan bagian pangkal maupun ujung. Hasil analisis sidik ragam pada Balam sejalan dengan MOE pada Bintangur, yang dipengaruhi oleh perlakuan pengawetan, bagian aksial, dan interaksi keduanya. Pada perlakuan infus, kayu Balam memiliki nilai MOE tertinggi di pangkal, menurun di tengah dan kembali meningkat di ujung yang berbeda nyata secara statistika. Perlakuan pengawetan yang berpengaruh terhadap MOE dimungkinkan akibat larutan bahan pengawet mengkristal dan mengering pada rongga kayu yang menyebabkan kayu menjadi lebih padat, sehingga menyebabkan peningkatan nilai MOE dan cenderung menyebabkan kayu menjadi lebih kuat dari sebelum perlakuan (Pangestuti et al., 2016). Selain itu, nilai MOE berhubungan dengan nilai MOR diakibatkan keduanya saling mempengaruhi sifat mekanis kayu (Lahtela, Hämäläinen, \& Kärki, 2013).

\subsubsection{Modulus of Rupture (MOR) atau Modulus Patah}

Hasil penelitian menunjukkan bahwa nilai MOR (Gambar 9) untuk pohon Bintangur pada arah aksial memiliki pola yang sama dengan nilai MOE. Kayu Bintangur yang diinfus memiliki nilai MOR tertinggi, sedangkan Bintangur bandage- wrapping memiliki nilai yang lebih rendah dibandingkan dengan kontrol. Hal ini dimungkinkan akibat bahan pengawet pada metode bandage-wrapping keluar selama perlakuan (Damayanti et al., 2020). Jika dilihat dari klasifikasi Den Berger, nilai MOR pohon Bintangur termasuk kelas kuat III baik kontrol maupun pohon Bintangur yang sudah diawetkan (Yani, 2013). Pada kayu Balam, berdasarkan klasifikasi oleh Den Berger, nilai MOR kelas kuat III untuk kontrol dan meningkat menjadi kelas kuat II untuk pohon Balam perlakuan (Yani, 2013).

Hasil analisis sidik ragam menunjukkan bahwa perlakuan pengawetan, bagian aksial pohon, dan interaksi keduanya berpengaruh terhadap nilai modulus patah pada pohon Bintangur dan Balam. Hal ini diduga akibat bahan pengawet yang terkristalisasi dan mengering pada rongga kayu sehingga kayu menjadi lebih padat, kuat dan mempengaruhi nilai modulus patahnya (Pangestuti et al., 2016). Pohon Bintangur bagian pangkal dari perlakuan infus memiliki nilai MOR yang berbeda nyata secara statistik. Nilai MOR kayu Balam kontrol lebih rendah dibandingkan yang sudah diawetkan, serta rata-rata bagian tengah memiliki nilai terkecil dan berbeda nyata dengan masing-masing bagian lainnya. 


\section{KESIMPULAN DAN SARAN}

Perlakuan pengawetan kayu pada pohon berdiri dengan metode infus dan bandage-wrapping mempengaruhi karakteristik kimia dan mekanis pada kayu Balam dan Bintangur yang telah diawetkan. Karakteristik kimia dan mekanis yang dipengaruhi oleh perlakuan pengawetan dan bagian aksial pada kedua pohon adalah sifat kimia (kadar lignin dan alfa selulosa) dan sifat mekanis (MOE dan MOR). Berdasarkan nilai MOE dan MOR, perlakuan pengawetan yang diterapkan mampu meningkatkan kekuatan kayu Bintangur dari kelas kuat IV menjadi kelas kuat III, sedangkan untuk kayu Balam tetap dikategorikan pada kelas kuat III. Perlakuan dengan metode infus pada Bintangur memiliki karakteristik kimia dan mekanis yang paling sesuai untuk dijadikan alternatif bahan baku untuk pembuatan jalur. Penelitian selanjutnya diperlukan untuk menguji keawetan kayu Balam dan Bintangur setelah diawetkan dengan metode infus dan bandage-wrapping.

\section{UCAPAN TERIMAKASIH}

Ucapan terimakasih disampaikan kepada Kementerian Riset, Teknologi dan Pendidikan Tinggi atas bantuan dana penelitian melalui program Insentif Riset Sistem Inovasi Nasional (INSINAS) tahun 2019-2020, serta Laboratorium Bioproduk Terintegrasi (iLaB) Pusat Penelitian Biomaterial LIPI atas bantuan fasilitas alat karakterisasi pendukung.

\section{DAFTAR PUSTAKA}

Achmadi, S. (1990). Kimia kayu. Bogor: IPB Press.

Amin, Y., Wahyuni, I., Darmawan, T., \& Dwianto, W. (2011). Sifat fisik dan mekanik cabang kayu Schizolobium amazonicum Ducke. Jurnal IImu Dan Teknologi Kayu Tropis, 9(2), 182-187.

Bahanawan, A, Kusumah, S. S., Darmawan, T., Ismadi, Masruchin, N., Sudarmanto,...Dwianto, W. (2019). Moisture content, color quantification and starch content of oil palm trunk (Elaeis guineensis Jacq.). IOP
Conference Series: Earth and Environmental Science, 374(1). https://doi.org/10.1088/17551315/374/1/012041

Bahanawan, A., Darmawan, T., \& Dwianto, W., (2020). Hubungan sifat berat jenis dengan sifat higroskopisitas melalui pendekatan nilai rerata kehilangan air. Jurnal Riset Industri Hasil Hutan, 12(1), 1-8. https://doi.org/http://dx.doi.org/10.2411 1/jrihh.v12i1.5643

Cahyono, T. D., Darmawan, W., Priadi, T., \& Iswanto, A. H. (2020). Flexural properties of heat-treatment samama (Anthocephalus macrophyllus) wood impregnated by boron and methyl metacrylate. Journal of the Korean Wood Science and Technology, 48(1), 76-85.

https://doi.org/10.5658/WOOD.2020.4 8.1.76

Damayanti, R., Sribudiani, E., Somadona, S., Djarwanto, Tarmadi, D., Amin, Y.,...Pramasari, D. A. (2020). The movement of boron compound by infusion method and combination of injection and bandage-wrapping. Journal of the Korean Wood Science and Technology, 48(4), 513-526. https://doi.org/10.5658/WOOD.2020.4 8.4.513

Departemen Pertanian. (1976). Indonesia forestry vademicum. Jakarta: Balai Penjelidikan Kehutanan

Fan, Y., Wang, Y., Yu, N., Deng, L., \& Chen, Z. (2016). Study on the retention and distributions of the copper-based preservative in standing tree Chinese Fir (Cunninghamia lanceolata). Advances in Materials Science and Engineering, (4), 1-9. https://doi.org/10.1155/2016/6163179

Fengel, D., \& G. Wegener. (1995). Kayu: kimia, ultrastruktur, reaksi-reaksi (Harjono Sastrohamijoyo (ed.)). Yogyakarta: Gajah Mada University Press.

Hunggurami, E., Ramang, R., \& Djenmakani, Y. (2014). Pengaruh tindakan pengawetan terhadap sifat mekanis kayu kelapa. Jurnal Teknik Sipil, 3(2), 149-160 
Jasni, J., Pari, G., \& Satiti, E. R. (2016). Komposisi kimia dan keawetan alami 20 jenis kayu indonesia dengan pengujian di bawah naungan. Jurnal Penelitian Hasil Hutan, 34(4), 323333.

https://doi.org/10.20886/jphh.2016.34. 4.323-333

Lahtela, V., Hämäläinen, K., \& Kärki, T. (2013). The effects of preservatives on the properties of wood after modification (Review paper). Baltic Forestry, 20(1), 189-203

Lelana, N. E., \& Ismanto, A. (2011). Toksisitas bahan pengawet boronkromium terhadap serangga dan jamur pelapuk kayu. Jurnal Penelitian Hasil Hutan, 29(2), 142-154

Lestari, E., Pramasari, D. A., Amin, Y., Adi, D. S., Bahanawan, A., \& Dwianto, W. (2017). The chemical components changes of platinum teak wood. The 6th International Symposium for Sustainable Humanosphere Humanosphere (pp. 165-171).

Loiwatu, E. M. M. (2016). Komponen kimia dan anatomi tiga jenis bambu dari Seram, Maluku. Agritech: Jurnal Fakultas Teknologi Pertanian UGM, 28(2), 76-83. https://doi.org/10.22146/agritech.9866

Lukmandaru, G. (2009). Pengukuran kadar ekstraktif dan sifat warna pada kayu teras jati doreng (Tectona grandis). Jurnal IImu Kehutanan, 3(2), 67-73. https://doi.org/10.22146/jik.1045

Luostarinen, K., \& Hakkarainen, K. (2019). Chemical composition of wood and its connection with wood anatomy in Betula pubescens. Scandinavian Journal of Forest Research, 34(7), 577-584.

https://doi.org/10.1080/02827581.201 9.1662939

Martawijaya, A. (1996). Keawetan Kayu dan Faktor yang mempengaruhinya. Bogor: Pusat Penelitian dan Pengembangan Hasil Hutan dan Sosial Ekonomi Kehutanan.

Nugroho, N., Bahtiar, E. T., Lestari, D. P., \& Nawawi, D. S. (2013). Variasi kekuatan tarik dan komponen kimia dinding sel pada empat jenis bambu.
IImu Dan Teknologi Kayu Tropis, 11(2), 153-160.

Pangestuti, E. K., Lashari, L., \& Hardomo, A. (2016). Pengawetan kayu sengon melalui rendaman dingin menggunakan bahan pengawet enbor sp ditinjau terhadap sifat mekanik. Jurnal Teknik Sipil Dan Perencanaan, 18(1), $55-64$. https://doi.org/10.15294/jtsp.v18i1.669 5

Pasaribu, G., Sipayung, B., \& Pari, G. (2007). Analisis komponen kimia empat jenis kayu asal Sumatera Utara. Jurnal Penelitian Hasil Hutan, 25(4), 329-333

Prakosa, G. G., Muttaqin, T., \& Suhestin, R. (2020). Sifat fisik dan mekanik kayu randu (Ceiba pentandra L. Gaerner) terdensifikasi dari hutan rakyat. Jurnal Riset Industri Hasil Hutan, 12(2), 93. https://doi.org/10.24111/jrihh.v12i2.63 49

Pramasari, D. A., Sondari, D., Adi, D. S., Widyaningrum, B. A., Fajar, A., Putri, R.,... Putri, E. H. (2020). Karakteristik pati berpori mikro dari tapioka hasil perlakuan amilase sebagai agen penjerapan minyak. Jurnal Teknologi \& Industri Hasil Pertanian, 25(2), 7180.

Pramasari, D. A., Wahyuni, I., Adi, D. S., Amin, Y., Darmawan, T., \& Dwianto, W. (2015). Effect of age on chemical component of platinum teak wood-a fast growing teak wood from LIPI. Proceedings of The 6th International Symposium of IWoRS, 211-216.

Rowell, R. M. (2012). Handbook of wood chemistry and wood composites, second edition. Florida: CRC Press. https://doi.org/10.1201/b12487

Sluiter, A., Hames, B., Ruiz, R., Scarlata, C., Sluiter, J., Templeton, D., Crocker, D. (2011). Determination of structural carbohydrates and lignin in biomass. NREL - Laboratory Analytical Procedure (LAP), TP-510-426.

Sokanandi, A., Pari, G., \& Setiawan, D. (2014). Komponen kimia sepuluh jenis kayu kurang dikenal: kemungkinan penggunaan sebagai bahan baku bioetanol. Jurnal Penelitian Hasil 
Hutan, 32(3), 209-220

Sribudiani, E., Somadona, S., Sulaeman, R., Syafrinal, Yusuf, S., Amin, Y, .... Djarwanto. (2019). Sifat fisis kayu berkualitas rendah dari Riau setelah melalui proses pengawetan pohon dengan teknik bandage dan infus. Wahana Forestra:Jurnal Kehutanan, 14(1), 30-37

Sumaryanto, A., Hadikusumo, S. A., \& Lukmandaru, G. (2013). Pengawetan kayu gubal jati secara rendaman dingin dengan pengawet boron untuk mencegah serangan rayap kayu kering. IImu Kehutanan, 7(2), 93-107

Sunyata, A. (2011). Sifat kimia kayu huru kuning. Laporan Penelitian, Fakultas Kehutanan.Yogyakarta: Institut Pertanian Yogyakarta

TAPPI. (1996). [TAPPI] Techincal Association of The Pulp and Paper Industry. TAPPI Test Method. Atlanta : TAPPI Press.

Wibisono, H. S., Jasni, \& Arsyad, W. O. M. (2018). Chemical composition and natural durability of eight wood species tested under the shade. Jurnal Penelitian Hasil Hutan, 36(1), 59-65

Wise, L., M, M., \& Addicco D'A. (1946). Chlorite holocellulose, its fractionation and bearing on summative wood analysis and studies on the hemicelluloses. Pap Trade J, 122, 3543.

Yani, A. (2013). Keteguhan sambungan kayu resak (Vatica rassak $\mathrm{BI}$ ) berdasarkan bentuk sambungan dan jumlah paku. Vokasi, 9(1), 51-60

Yunanta, R. R. K., Lukmandaru, G., \& Fernandes, A. (2014). Chemical properties of Shorea retusa, Shorea macroptera, and Shorea macrophylla woods. Jurnal Penelitian Dipterokarpa, $8,15-24$

Zaki, J., Muhammed, S., Shafie, A., \& Daud, W. R. . (2012). Chemical properties of Juvenile Latex Timber clone rubberwood trees. The Malaysian Journal of Analytical Sciences, 16(3), 228-234 
Jurnal Riset Industri Hasil Hutan Vol.13, No.2, Desember 2021: 83 - 98 